\title{
KEPASTIAN HUKUM PENGUASAAN TANAH MELALUI PENDAFTARAN TANAH SISTEMATIS LENGKAP DI KOTA BATU
}

\author{
Isdiyana Kusuma Ayu*
}

Fakultas Hukum Universitas Islam Malang, Jalan MT Haryono Nomor 193, Kota Malang

\begin{abstract}
Systematic and Complete Land Registration (PTSL) is a government program to implement single land mapping in Indonesia. The target of PTSL is only for uncertified land in a village or suburb. One of the areas implementing PTSL program is Batu City that had previously applied National Agrarian Operation Project (PRONA). As a new registration system, PTSL is worthy to discuss and analyze whether or not systematic and complete land registration has already provided legal certainty for land owners. According to the research result and analysis, it can be concluded that there are many hindering factors experienced by Agrarian Office of Batu City, PTSL participants and village officials in Batu City. Land registration through PTSL program is, however, still substantial in providing legal certainty for all participants.
\end{abstract}

Keywords: rule of law, land registration, systematic.

\section{Intisari}

Pendaftaran Tanah Sistematis Lengkap (PTSL) merupakan program pemerintah untuk mewujudkan peta tunggal di Indonesia. Sasaran PTSL yaitu bidang tanah yang belum memiliki sertifikat dalam satu kelurahan atau desa. Salah satu daerah yang mengikuti Program PTSL yaitu Kota Batu yang sebelumnya juga mengikuti Proyek Operasi Nasional Agraria (PRONA). Sebagai sistem pendaftaran yang baru, PTSL menarik untuk dikaji dan dianalisis agar dapat diketahui faktor penghambat dan pendukung dalam pelaksanaan, perlu pula dikaji dan dianalisis apakah pendaftaran tanah sistematis lengkap telah memberikan kepastian hukum kepada pemilik tanah. Berdasarkan hasil kajian dan analisis dapat disimpulkan bahwa banyak ditemukan faktor penghambat yang muncul dari pihak Kantor Pertanahan Kota Batu, Peserta PTSL, dan pihak Desa atau Kelurahan di Kota Batu. Pendaftaran tanah melalui Program PTSL tetap memberikan kepastian hukum kepada pesertanya.

Kata Kunci: kepastian hukum, pendaftaran tanah, sistematis.

\section{Pokok Muatan}

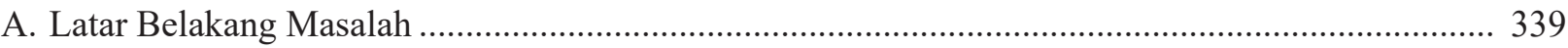

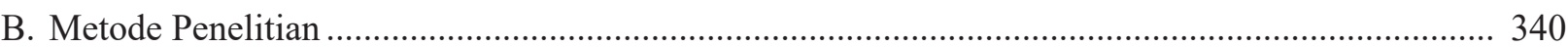

C. Hasil Penelitian dan Pembahasan ........................................................................................... 340

1. Pendaftaran Tanah dan Pendaftaran Tanah Sistematis Lengkap................................................ 340

2. Pelaksanaan Pendaftaran Tanah Sistematis Lengkap di Kota Batu .............................................. 342

3. Kepastian Hukum Penguasaan Tanah melalui Pendaftaran Tanah Sistematis Lengkap

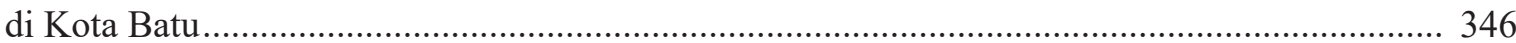

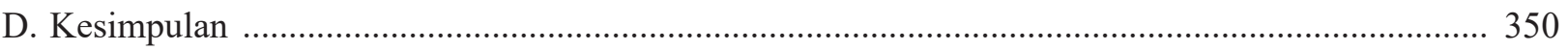

Alamat korespondensi: isdiyana@unisma.ac.id. 


\section{A. Latar Belakang Masalah}

Pendaftaran tanah merupakan kegiatan yang dilakukan oleh Pemerintah untuk memberikan kepastian hukum dan perlindungan hukum terhadap pemegang hak atas tanah. Kegiatan pendaftaran tanah terdiri dari pendaftaran tanah pertama kali dan pemeliharaan data. Kegiatan pendaftaran tanah pertama kali dapat dilakukan secara sporadis maupun sistematis. Pendaftaran tanah pertama kali melalui sporadis berarti pendaftaran tanah tersebut dilakukan oleh sekelompok orang yang akan mendaftarkan tanah yang masih berstatus hak lama. Pendaftaran tanah pertama kali melalui sistematis merupakan pendaftaran tanah pertama kali yang dilaksanakan oleh Pemerintah terhadap satu kelurahan yang masih belum bersertifikat tanah.

Kegiatan pendaftaran tanah pertama kali yaitu Proyek Operasi Nasional Agraria (PRONA) yang dilaksanakan sejak tahun 1981 berdasarkan Keputusan Menteri Dalam Negeri Nomor 189 Tahun 1981 tentang Proyek Operasi Nasional Agraria. Tujuan PRONA yaitu upaya dalam melaksanakan Garis-garis Besar Haluan Negara dan Catur Tertib di bidang pertanahan, khususnya dalam pemberian sertifikat kepada masyarakat yang belum memilikinya. Kelemahan dari PRONA yaitu sejak 1981 hingga 2016 ternyata hanya berhasil menyertifikatkan tanah sebanyak 44\% saja, sehingga masih kurang 56\% di seluruh Indonesia. ${ }^{1}$ Upaya percepatan pendaftaran tanah melalui PRONA tidak mencapai target sehingga digagas pada tahun 2015 , program pemerintah yang juga melaksanakan pendaftaran tanah pertama kali yaitu Pendaftaran Tanah Sistematis Lengkap (PTSL).

PTSL merupakan kegiatan pendaftaran tanah untuk pertama kali yang dilakukan secara serentak bagi semua obyek pendaftaran tanah di seluruh wilayah Republik Indonesia dalam satu wilayah desa/kelurahan, atau nama lainnya yang setingkat dengan itu, yang meliputi pengumpulan dan penetapan kebenaran data fisik dan data yuridis mengenai satu atau beberapa obyek pendaftaran tanah untuk keperluan pendaftarannya. ${ }^{2}$

Latar belakang pelaksanaan program PTSL yaitu Pemerintah masih menemukan tanah di Indonesia yang belum bersertifikat atau tidak memiliki sertifikat. Sertifikat tanah merupakan alat bukti yang kuat terhadap penguasaan tanah oleh masyarakat. Pemerintah tidak membebankan biaya kepada masyarakat untuk proses pendaftaran tanah, melainkan hanya membebankan biaya administrasinya saja, seperti penyediaan surat tanah untuk tanah yang belum memiliki surat tanah, pembuatan dan pemasangan tanda batas, pajak peralihan, serta biaya materai, fotokopi bukti kepemilikan tanah seperti letter $C$, ataupun biaya saksi.

Salah satu daerah di Indonesia yang dapat obyek dari PTSL yaitu Kota Batu. Kota Batu yang terletak di Provinsi Jawa Timur dengan luas wilayah 19908,72 Ha dengan jumlah 3 kecamatan, 4 kelurahan, dan 24 desa $^{3}$. Berdasarkan data Kantor Pertanahan Kota Batu, tanah yang sudah terdaftar sampai 2017 lalu, kurang lebih sebanyak 42.482 bidang. Sementara tanah yang belum terdaftar sebanyak 54.708 bidang. Ditargetkan, semua tanah yang belum terdaftar itu sudah terdaftar pada 2025 mendatang.

Kota Batu mendapatkan bagian 514 sertifikat gratis dari PTSL tahun 2016. Sertifikat tersebut oleh Kantor Pertanahan Kota Batu diberikan kepada empat desa, yaitu Desa Sumberejo, Desa Pesanggrahan, Desa Oro-oro Ombo, dan Desa Tulungrejo ${ }^{4}$, sedangkan pada tahun 2017, Kepala Kantor Pertanahan Kota Batu menyebutkan terdapat 1000 bidang yang masuk dalam PTSL 2017. Pada

Ihsanuddin. "Jokowi: Prona Sudah 35 Tahun, baru 44 Persen Tanah Warga Bersertifikat", https://nasional.kompas.com/ read/2016/10/16/12474581/jokowi.prona.sudah.35.tahun.baru.44.persen.tanah.warga.bersertifikat, diakses 12 November 2018.

Lihat Pasal 1 angka 2 Peraturan Menteri Agraria dan Tata Ruang/Kepala Badan Pertanahan Nasional Republik Indonesia Nomor 6 Tahun 2018 tentang Pendaftaran Tanah Sistematis Lengkap (Berita Negara Republik Indonesia Tahun 2018 Nomor 501),

Badan Pusat Statistik Kota Batu, "Statistik Daerah Kota Batu 2016”, Publikasi Statistik Daerah Kota Batu 2016 , September 2016 , hlm. 1.

Roy Mastur, "BPN Beri 514 Sertifikat Gratis Kota Batu”, http://www.rri.co.id/post/berita/248262/daerah/bpn_beri_514_sertifikat_gratis_ kota_batu.html, diakses 17 Juni 2017. 
tahun 2018 ditargetkan 10.000 bidang tanah telah bersertifikat melalui program PTSL.

Jumlah wilayah Kota Batu yang sudah bersertifikat tidak sampai $60 \%$ ini menyebabkan Kota Batu menjadi daerah yang dipilih untuk menjalankan PTSL. Tujuan dari PTSL yaitu untuk mempercepat pemetaan bidang tanah di Kota Batu. Selain itu, PTSL yang dilaksanakan di Kota Batu, pada dasarnya sebagai bentuk perhatian dari Pemerintah untuk memberikan kepastian hukum dan perlindungan hukum hak atas tanah masyarakat, sehingga dapat meningkatkan kesejahteraan dan kemakmuran masyarakat dan ekonomi negara, serta mengurangi dan mencegah sengketa dan konflik pertanahan yang terjadi di masyarakat Kota Batu.

Pelaksanaan PTSL di Kota Batu merupakan kegiatan yang bertujuan untuk memberikan kepastian dan perlindungan hukum terhadap masyarakat. PTSL merupakan kegiatan yang dilaksanakan secara sistematis, artinya kegiatan pendaftaran pertama kali yang dilakukan secara serentak yang meliputi semua obyek pendaftaran tanah yang belum terdaftar dalam wilayah atau bagian wilayah suatu desa/kelurahan. Namun, pelaksanaan PTSL di Indonesia tidak berjalan dengan mulus karena banyak kendala yang dihadapi oleh petugas di lapangan. Seperti bidang tanah yang belum memenuhi syarat untuk diterbitkan sertifikat, bidang tanah yang masih dalam keadaan sengketa atau perkara di Pengadilan, subyek bidang tanah yang tidak diketahui, tidak jelas, atau tidak berada di tempat, dan batas tanah yang tidak jelas. ${ }^{5}$

Berdasarkan uraian tersebut, rumusan masalah dalam penelitian ini adalah, Pertama, pengertian pendaftaran tanah dan pendaftaran tanah sistematis lengkap. Kedua, pelaksanaan PTSL di Kota Batu. Ketiga, kepastian hukum penguasaan tanah melalui pendaftaran tanah sistematis lengkap di Kota Batu.

\section{B. Metode Penelitian}

Jenis penelitian yang digunakan dalam penelitian ini adalah yuridis empiris dengan menggunakan metode pendekatan yuridis sosiologis. Penelitian ini meninjau dan menganalisis obyek penelitiannya terhadap implementasi Peraturan Menteri Agraria dan Tata Ruang/ Kepala Badan Pertanahan Nasional Nomor 6 Tahun 2018 tentang Pendaftaran Sistematis Lengkap (selanjutnya disebut Permen ATR/BPN No 6/2018), untuk mengetahui kepastian hukum penguasaan tanah melalui PTSL di Kota Batu. Lokasi penelitian di Kota Batu, khususnya di Desa Oro-Oro Ombo yang merupakan desa yang memiliki jumlah tempat wisata yang sering dikunjungi oleh masyarakat dan Kelurahan Dadaprejo yang merupakan kelurahan yang menjadi tempat pelaksanaan PTSL Kota Batu 2018.

Sumber data yang digunakan dibedakan menjadi dua, yaitu sumber data primer dan sumber data sekunder. Sumber data primer diperoleh dari lapangan melalui wawancara dengan pihak yang bersangkutan, seperti perangkat desa dengan Kepala Desa Oro-Oro Ombo, Bapak Wiweko, Lurah Dadaprejo, Bapak Abdul Salam, Kasi Hubungan Hukum Pertanahan Kantor Pertanahan Kota Batu yaitu Agus Harianto, dan Wira Santyani, S.SiT, sebagai Kaur Umum dan Kepegawaian Kantor Pertanahan Kota Batu dan Peserta PTSL. Sumber data sekunder yaitu data-data yang diperoleh dari kajian pustaka, peraturan perundang-undangan, dan buku-buku literatur.

\section{Hasil Penelitian dan Pembahasan \\ 1. Pendaftaran Tanah dan Pendaftaran Tanah Sistematis Lengkap \\ Pendaftaran tanah merupakan serangkaian kegiatan yang dilakukan oleh Pemerintah secara terus menerus, berkesinambungan, dan teratur. Asas pendaftaran tanah yang dilaksanakan di Indonesia}

Erwin Hutapea,TakSelaluBerjalan Mulus, Pendaftaran Tanah TerkendalaEmpatHal, https://properti.kompas.com/read/2018/12/17/183000721/ tak-selalu-berjalan-mulus-pendaftaran-tanah-terkendala-empat-hal?page=all, diakses pada tanggal 10 April 2019. 
yaitu asas sederhana, aman, terjangkau, mutakhir, dan terbuka. Asas yang melandasi kegiatan pendaftaran tanah di Indonesia lebih mengutamakan kepentingan masyarakat dalam hal penguasaan atas suatu bidang tanah atau satuan rumah susun yang sesuai dengan ketentuan yang ada dengan biaya yang terjangkau. Pendaftaran tanah diatur dalam Pasal 19 Undang-Undang Nomor 5 Tahun 1960 tentang Pokok-Pokok Agraria (UUPA). Pasal 19 ayat (1) UUPA menyebutkan bahwa: ${ }^{6}$

(1) Untuk menjamin kepastian hukum, oleh Pemerintah diadakan pendaftaran tanah di seluruh wilayah Republik Indonesia, menurut ketentuan yang diatur dengan Peraturan Pemerintah.

Pendaftaran tanah yang dilaksanakan di Indonesia memiliki tujuan untuk Pemerintah, Masyarakat, dan pihak ketiga, tujuan tersebut antara lain:?

a. Memberikan kepastian hukum dan perlindungan hukum kepada pemegangan hak atas suatu bidang tanah dalam bentuk pemberian sertifikat hak atas tanah

b. Menyediakan informasi kepada pihakpihak yang berkepentingan agar dengan mudah untuk memperoleh data, baik data fisik dan data yuridis yang sudah terdaftar terbuka untuk umum.

c. Terselenggaranya tertib administrasi, baik dalam hal peralihan, pembebanan, dan hapusnya hak atas bidang tanah dan hak milik satuan rumah susun yang wajib didaftarkan di Kantor Pertanahan setempat.

Salah satu kegiatan pendaftaran tanah yaitu kegiatan pendaftaran tanah untuk pertama kali. Kegiatan pendaftaran tanah untuk pertama kali merupakan kegiatan yang dilakukan terhadap obyek tanah yang belum didaftarkan berdasarkan Peraturan Pemerintah Nomor 10 Tahun 1961 tentang Pendaftaran Tanah atau Peraturan Pemerintah Nomor 24 Tahun 1997 tentang Pendaftaran Tanah (PP No 24/1997). Bentuk kegiatan pendaftaran tanah pertama kali dibagi menjadi dua yaitu:

a. Pendaftaran tanah secara sistematis, artinya pendaftaran tanah untuk pertama kali yang dilakukan secara serentak meliputi semua obyek pendaftaran tanah yang belum didaftar dalam wilayah atau bagian wilayah suatu desa/kelurahan.

b. Pendaftaran tanah secara sporadis, artinya pendaftaran tanah untuk pertama kali mengenai satu atau beberapa obyek pendaftaran tanah dalam wilayah/bagian wilayah suatu desa/kelurahan secara individual atau masal.

Pendaftaran tanah untuk pertama kali telah dilaksanakan oleh Pemerintah Indonesia melalui Program Pendaftaran Tanah Sistematis Lengkap (PTSL). Dasar hukum PTSL dapat dilihat dalam Peraturan Menteri Agraria dan Tata Ruang/Kepala Badan Pertanahan Nasional Nomor 35 Tahun 2016. Peraturan tersebut diubah dengan Peraturan Menteri Agraria dan Tata Ruang/Kepala Badan Pertanahan Nasional Nomor 1 Tahun 2017 tentang Perubahan atas Peraturan Menteri Agraria dan Tata Ruang/Kepala Badan Pertanahan Nasional Nomor 35 Tahun 2016 tentang Percepatan Pelaksanaan Pendaftaran Tanah Sistematis Lengkap.

Peraturan tersebut di atas diubah kembali menjadi Peraturan Menteri Agraria dan Tata Ruang/ Kepala Badan Pertanahan Nasional Nomor 6 Tahun 2018 (Permen ATR/BPN No 6/2018). Pembaruan dari aturan terhadap PTSL terjadi karena aturanaturan yang terkait dengan PTSL sebelumnya masih

Pasal 19 ayat (1) Undang-Undang Nomor 5 Tahun 1960 tentang Pokok-Pokok Agraria (Lembaran Negara Republik Indonesia Tahun 1960 Nomor 104, Tambahan Lembaran Negara Nomor 2043).

Pasal 3 dan Pasal 4 Peraturan Pemerintah Nomor 24 Tahun 1997 tentang Pendaftaran Tanah (Lembaran Negara Republik Indonesia Nomor 59 Tahun 1997, Tambahan Lembaran Negara Republik Indonesia Nomor 3696). 
memerlukan penyempurnaan substansi atau materi untuk menyesuaikan pada ketentuan peraturan perundang-undangan terkait pendaftaran tanah maupun ketentuan pertanahan lainnya. ${ }^{8}$

Dasar hukum PTSL yang berlaku saat ini yaitu Instruksi Presiden Nomor 2 Tahun 2018 tentang Percepatan Pendaftaran Tanah Sistematis Lengkap, Peraturan Menteri Agraria dan Tata Ruang/Badan Pertanahan Nasional Nomor 6 Tahun 2018 tentang Pendaftaran Tanah Sistematis Lengkap, Keputusan Bersama Menteri Agraria dan Tata Ruang/ Kepala Badan Pertanahan Nasional, Menteri Dalam Negeri, Menteri Desa, Pembangunan Daerah Tertinggal dan Transmigrasi Nomor 25/SKB/V/2017, Nomor 590-3167A Tahun 2017, Nomor 34 Tahun 2017 tentang Pembiayaan Persiapan Pendaftaran Tanah Sistematis.

PTSL merupakan kegiatan pendaftaran tanah untuk pertama kali yang dilakukan secara serentak bagi semua obyek pendaftaran tanah di seluruh wilayah Republik Indonesia dalam satu wilayah desa/kelurahan. Kegiatan ini bertujuan untuk mewujudkan pemberian kepastian hukum dan perlindungan hukum hak atas tanah masyarakat. Asas yang digunakan dalam pelaksanaan PTSL yaitu sederhana, cepat, lancar, aman, adil, merata dan terbuka, serta akuntabel. PTSL yang dilaksanakan oleh Pemerintah pada dasarnya untuk meningkatkan kesejahteraan dan kemakmuran rakyat dan ekonomi negara, selain itu juga untuk mengurangi dan mencegah sengketa dan konflik pertanahan akibat tidak adanya alat bukti yang kuat terhadap penguasaan suatu bidang tanah.

\section{Pelaksanaan Pendaftaran Tanah Sistema- tis Lengkap di Kota Batu}

Kota Batu merupakan salah satu kota di Jawa Timur yang mengikuti Program PTSL pada tahun 2018. Kota Batu terdiri dari 3 kecamatan, yaitu Kecamatan Batu, Kecamatan Bumiaji, dan Kecamatan Junrejo. Kecamatan Batu terdiri dari Desa Ngaglik, Desa Songgo Kerto, Desa Pesanggrahan, Desa Sisir, Desa Temas, Desa OroOro Ombo, Desa Sidomulyo, dan Desa Sumberejo. Kecamatan Bumiaji terdiri dari Desa Bumiaji, Desa Pandan Rejo, Desa Giripurno, Desa Bulukerto, Desa Sumber Gondo, Desa Tulung Rejo, Desa Gunung Sari, Desa Punten, dan Desa Sumber Brantas. Kecamatan Junrejo terdiri dari Desa Junrejo, Desa Mojorejo, Kelurahan Dadaprejo, Desa Pendem, Desa Torongrejo, Desa Beji, dan Desa Tlekung.

Landasan pelaksanaan yang digunakan oleh Kantor Pertanahan Kota Batu dalam melaksanakan Program PTSL telah diatur dalam Permen ATR/ BPN No 6/2018. Pasal 4 ayat (4) Permen ATR/ BPN No 6/2018 menyebutkan tahapan pelaksanaan PTSL sebagai berikut: ${ }^{9}$
a. Perencanaan;
b. Penetapan lokasi;
c. Persiapan;
d. Pembentukan dan penetapan panitia ajudikasi PTSL dan satuan tugas;
e. Penyuluhan;
f. Pengumpulan data fisik dan pengumpulan data yuridis;
g. Penelitian data yuridis untuk pembuktian hak;
h. Pengumuman data fisik dan data yuridis serta pengesahannya;
i. Penegasan konversi, pengakuan hak dan pemberian hak;
j. Pembukuan hak;
k. Penerbitan sertifikat hak atas tanah;
1. Pendokumentasian dan penyerahan hasil kegiatan;
m. Pelaporan.

Setiap kegiatan PTSL ditujukan kepada seluruh obyek pendaftaran tanah di seluruh wilayah Republik Indonesia, baik yang sudah ada tanda batasnya ataupun yang akan ditetapkan tanda batasnya dalam kegiatan PTSL. Perencanaan

Dasar Menimbang huruf b Peraturan Menteri Agraria dan Tata Ruang/Kepala Badan Pertanahan Nasional Republik Indonesia Nomor 6 Tahun 2018 tentang Pendaftaran TanahSistematis Lengkap (Berita Negara Republik Indonesia Tahun 2018 Nomor 501).

Pasal 4 ayat (4) Peraturan Menteri Agraria dan Tata Ruang/ Kepala Badan Pertanahan Nasional Nomor 6 Tahun 2018 tentang Pendaftaran Tanah Sistematis Lengkap (Berita Negara Republik Indonesia Tahun 2018 Nomor 501), 
dilakukan oleh setiap kantor pertanahan khususnya Kepala Kantor Pertanahan untuk menetapkan lokasi penyebaran target PTSL yang dikhususkan pada beberapa desa/kelurahan, dan atau kecamatan. PTSL Kota Batu telah direncanakan oleh Kepala Kantor Pertanahan Kota Batu antara tanggal 20 hingga 25 Januari 2018 untuk menerbitkan SK Lokasi Ajudikasi PTSL, yaitu pada Desa Pesanggrahan, Desa Oro-Oro Ombo, Desa Torongrejo, dan Desa Sumberejo. ${ }^{10}$

Kriteria untuk penentuan lokasi yaitu ketersediaan anggaran PTSL dalam APBN/APBD, PNBP, CSR, atau sumber dana lainnya. ${ }^{11}$ Penetapan lokasi tersebut lebih diprioritaskan terhadap daerah yang sebelumnya telah melaksanakan PRONA seperti Desa Oro-Oro Ombo, dan pertimbangan kemampuan petugas pelaksana PTSL pada masingmasing Kantor Pertanahan. Letak dari keempat desa tersebut juga berdekatan satu dengan lainnya.

Setelah perencanaan dan penetapan lokasi, langkah selanjutnya adalah melakukan persiapan. Persiapan berdasarkan Pasal 4 ayat (1) Permen ATR/BPN No 6/2018, pertama harus dilakukan oleh Kepala Kantor Pertanahan yaitu terkait sarana dan prasarana pelaksanaan Kegiatan PTSL, seperti alat ukur dan lokasi tempat kerja Panitia Ajudikasi. Kedua, sumber daya manusia yang perlu disiapkan oleh Kepala Kantor Pertanahan dengan menetapkan Panitia Ajudikasi sebagai pelaksana PTSL. Ketiga, kebutuhan transportasi, PTSL merupakan pendaftaran pertama kali dimana pihak dari Kantor Pertanahan Kota Batu harus datang langsung ke lokasi untuk melakukan pengukuran, sehingga perlu adanya akomodasi untuk mempermudah kegiatan tersebut. Keempat, koordinasi dengan aparat pemerintah lainnya. Aparat pemerintah yang berkaitan dengan pelaksanaan PTSL yaitu perangkat desa atau kelurahan, Perangkat Desa Oro-oro Ombo, dan Pegawai Kelurahan Dadaprejo, yang juga masuk dalam bagian Panitia Ajudikasi.
Setelah persiapan selesai, langkah selanjutnya yang dilakukan adalah Kepala Kantor Pertanahan Kota Batu membentuk dan menetapkan Panitia Ajudikasi melalui Surat Keputusan Kepala Kantor Pertanahan Kota Batu. Kegiatan PTSL Kota Batu tahun 2018 diketuai oleh Bapak Agus Harianto, Kepala Seksi Bagian Hubungan Hukum Pertanahan, sebagai Ketua Panitia Ajudikasi yang bertugas dan berwenang untuk memimpin dan bertanggung jawab terhadap seluruh pelaksanaan program kegiatan ajudikasi.

Panitia Ajudikasi dalam bertugas juga dibantu oleh Satuan Tugas (Satgas) yang terdiri dari Satgas Fisik, Satgas Yuridis, dan Satgas Administrasi yang akan tetap saling berkoordinasi dengan Panitia Ajudikasi. Ketua Panitia Ajudikasi PTSL Kota Batu, Bapak Agus Harianto, bersama tim melakukan penyuluhan secara bertahap di masing-masing desa yang berpartisipasi dalam PTSL tahun 2018.

Penyuluhan yang dilakukan tidak hanya melibatkan kantor pertanahan Kota Batu, melainkan turut mengundang pihak kepolisian, kejaksaan, dan perbankan. Tujuan melibatkan pihak-pihak tersebut yaitu agar terjadi keterbukaan dalam pelaksanaan PTSL sehingga tidak ada pihak yang dirugikan. Sasaran penyuluhan yaitu masyarakat yang sudah memiliki atau belum memiliki sertifikat tanah. Dalam kegiatan penyuluhan ini, penyuluhan di Desa Oro-Oro Ombo dan Kelurahan Dadaprejo berjalan dengan baik.

Hal ini terlihat dari antusiasme warga dalam mengikuti penyuluhan, dengan mengajukan beberapa pertanyaan khususnya dengan biaya yang dikeluarkan saat PTSL berlangsung. Namun, tidak semua warga dapat hadir dalam penyuluhan karena bersamaan dengan waktu bekerja. Selain itu, masih terdapat warga yang sudah lanjut usia dan berada di tingkat perekonomian yang rendah, sehingga tidak mudah untuk memahami apa yang dipaparkan oleh Panitia Ajudikasi, sehingga perlu adanya pendekatan

10 Hasil wawancara dengan Ibu Wira Sentyani, S.SiT, Kaur Umum Kepegawaian Kantor Pertanahan Kota Batu.

11 Pasal 7 ayat (4) Peraturan Menteri Agraria dan Tata Ruang/ Kepala Badan Pertanahan Nasional Nomor 6 Tahun 2018 tentang Pendaftaran Tanah Sistematis Lengkap (Berita Negara Republik Indonesia Tahun 2018 Nomor 501), 
langsung antara Panitia Ajudikasi dengan warga.

Pengumpulan data fisik dan data yuridis dilakukan oleh Panitia Ajudikasi. Dalam pelaksanaan PTSL di Kota Batu, pihak yang paling berperan dalam pengumpulan data yuridis yaitu dari pihak desa. Pihak-pihak yang berperan dalam PTSL di lingkungan Desa Oro-oro Ombo dan Kelurahan Dadaprejo dilakukan oleh Panitia Desa yang terdiri dari Karang Taruna, Tokoh Pemuda, dan Tokoh Masyarakat, khususnya Ketua RT dan RW. Ketiga elemen tersebut mendapatkan Surat Keputusan dari Kepala Desa Oro-oro Ombo dan Lurah Dadaprejo untuk memperkuat tugas Panitia Desa/Kelurahan ketika melakukan pendataan di masyarakat. Peran Ketua RT dan RW yaitu mengumpulkan berkas, mendampingi pada saat pengukuran, dan menyelesaikan masalah yang ada masyarakat desa. Ketika permasalahan tersebut tidak dapat diselesaikan, maka akan dibawa ke Kantor Desa untuk diselesaikan.

Setelah data yuridis sudah terkumpul, maka pengumpulan data fisik akan dilakukan oleh petugas ukur dari Kantor Pertanahan Kota Batu. Namun, jumlah petugas ukur di Kantor Pertanahan Kota Batu masih kurang dan tidak sampai 20 petugas ukur, dengan setiap tim terdiri dari 2 orang. Rata-rata pengukuran yang dilakukan oleh setiap tim yaitu 10 bidang tanah dalam satu hari. ${ }^{12}$ Akibat perbandingan antara luas tanah yang diukur dengan jumlah petugas ukur yang tidak sebanding, maka penyelesaian pengukuran di Kota Batu untuk kegiatan PTSL berlangsung lama. Selain itu, faktor penghambat lain yaitu, jarak satu bidang tanah dengan bidang tanah lainnya yang jauh dan cuaca yang tidak mendukung di Kota Batu.

Setelah bidang tanah sudah diukur untuk memenuhi data fisik, langkah selanjutnya adalah pembuktian hak dengan melakukan penelitian data yuridis. Penelitian tersebut terdiri dari pemeriksaan riwayat kepemilikan tanah yang dituangkan dalam Risalah Penelitian Data Yuridis. Panitia
Ajudikasi Kota Batu akan meneliti terkait riwayat tanah berdasarkan bukti kepemilikan yang telah dikumpulkan oleh peserta PTSL di Desa Oro-Oro Ombo dan Kelurahan Dadaprejo. Tujuan penelitian ini yaitu untuk keperluan pembuktian hak.

Kemudahan dari pendaftaran melalui PTSL yaitu ketika riwayat kepemilikan tanah peserta PTSL tidak lengkap, maka dapat dilengkapi dan dibuktikan dengan surat pernyataan tertulis bermaterai cukup dengan tentang kepemilikan dan/atau penguasaan fisik bidang tanah dengan itikad baik dari pihak yang bersangkutan. Indikator itikad baik yaitu tidak ada pihak yang keberatan atas tanah yang dimiliki atau tidak dalam keadaan sengketa, tidak termasuk asset pemerintah, dan bukan kawasan hutan. Meskipun terdapat kemudahan tersebut, kekuatan pembuktian dari surat pernyataan bermaterai yang dibuat oleh Peserta PTSL sama dengan akta di bawah tangan.

Kekuatan pembuktian akta di bawah tangan adalah orang terhadap siapa akta di bawah tangan tersebut digunakan diwajibkan membenarkan atau memungkiri tanda tangannya. Ketika tandatangan tersebut dipungkiri, maka hakim harus memerintahkan agar kebenaran akta diperiksa. Namun, ketika tanda tangan diakui oleh yang bersangkutan maka akta di bawah tangan tersebut mempunyai kekuatan dan menjadi bukti yang sempurna. ${ }^{13}$ Sehingga, dapat disimpulkan bahwa kekuatan pembuktian dari surat pernyataan yang dibuat oleh Peserta PTSL adalah tidak otomatis memiliki kekuatan pembuktian yang sempurna.

Langkah selanjutnya yaitu pengumuman data fisik dan data yuridis serta pengesahannya. Pengumuman dalam PTSL hanya dilakukan selama 14 hari kalender dan diumumkan di Kantor Panitia Ajudikasi PTSL dan Kantor Kepala Desa/Kelurahan. Hal ini juga diberlakukan dalam pelaksanaan PTSL di Kota Batu. Lama waktu 14 hari kalender tersebut digunakan untuk diadakannya pengajuan keberatan atau kekuranglengkapan data. Ketika terdapat pihak yang keberatan terhadap data fisik atau data 
yuridis yang diumumkan tersebut, maka pihak yang keberatan wajib memberitahukan secara tertulis agar segera mengajukan gugatan ke Pengadilan.

Ketentuan 14 hari kalender untuk melakukan pengumuman berbeda dengan ketentuan dalam Pasal 26 PP NO 24/1997, yang menentukan bahwa pengumuman pendaftaran pertama kali secara sistematik dilakukan selama 30 hari kerja. Alasan Pemerintah mempersingkat waktu tersebut karena PTSL merupakan pendaftaran tanah secara massal yang diketahui oleh masyarakat umum dan merupakan kegiatan percepatan pendaftaran tanah antara 4 hingga 6 bulan sejak sosialisasi kegiatan, sehingga pengumumannya lebih singkat dan ketika ada sengketa tanah akan segera diketahui. ${ }^{14}$

Ketika pengumuman selama 14 hari kalender tidak ada pihak yang keberatan atau data sudah lengkap maka hal yang harus dilakukan lagi yaitu penegasan konversi, pengakuan hak, atau pemberian hak. Perbedaan dari ketiga kegiatan tersebut ketika penegasan konversi yaitu diberikan pada bidang tanah yang alat bukti tertulisnya lengkap atau alat bukti tertulisnya tidak lengkap, tetapi terdapat keterangan saksi maupun pernyataan yang bersangkutan. Pengakuan hak akan diberikan kepada tanah yang dibuktikan dengan kenyataan penguasaaan fisiknya selama 20 tahun secara terus menerus. Sedangkan pemberian hak diberikan kepada tanah yang termasuk tanah Negara dengan mengusulkan secara kolektif oleh Kepala Kantor Pertanahan. Pelaksanaan PTSL di Kota Batu lebih didominasi oleh penyelesaian kegiatan dengan penegasan konversi karena memang mayoritas tanah di Kota Batu masih belum bersertifikat.

Tahap selanjutnya yaitu pembukuan hak yang merupakan kegiatan dimana data fisik dan data yuridis yang dibukukan dalam buku tanah yang ditandatangani oleh Ketua Panitia Ajudikasi atas nama Kepala Kantor Pertanahan. Pembukuan hak ini berisikan pembatasan dalam pemindahan hak, penggunaan tanah menyangkut garis sempadan pantai, sungai, dan pembatasan penggunaan tanah hak dalam kawasan lindung. Ketika sudah ditandatangani dan sudah memenuhi syarat untuk diberikan tanda bukti haknya, sertifikat hak atas tanah akan diterbitkan dan diberikan kepada masyarakat.

Hambatan yang dialami oleh Kantor Pertanahan Kota Batu dapat diselesaikan dengan menambah Pegawai Kantor Pertanahan Kota Batu, khususnya petugas ukur. petugas ukur dari Kantor Pertanahan Kota Batu yang masih kurang menyebabkan pengukuran tanah warga menjadi lebih lama dan tidak segera selesai, karena satu hari hanya dapat dilakukan pengukuran sebanyak 10 bidang. Cara yang dapat segera dilakukan oleh Kantor Pertanahan adalah bekerja sama dengan surveyor berlisensi milik swasata.

Hal ini juga diikuti dengan merekrut petugas ukur baru agar dapat mengurangi biaya kerja sama tersebut. Selain itu, rangkap jabatan antara Petugas Harian Kantor Pertanahan dengan Panitia Ajudikasi juga dapat memperlambat jalannya kegiatan PTSL dan kinerja pelayanan lainnya. Kantor Pertanahan Kota Batu dapat menentukan Panitia Ajudikasi yang merupakan Pegawai Kantor Pertanahan Kota Batu yang tidak berperan langsung dengan masyarakat, seperti bagian loket yang bertemu langsung dengan masyarakat untuk melakukan pendaftaran tanah atau pemeliharaan data.

Masyarakat yang ikut sebagai peserta PTSL lebih didominasi oleh masyarakat yang memiliki tingkat perekonomian yang rendah dan sudah lanjut usia, sehingga ketika diberikan sosialisasi terkait program PTSL dengan menggunakan Bahasa Indonesia, terkadang tidak mengerti dan perlu diberikan pemahaman satu persatu. Ketika dilakukan sosialisasi mengenai program ini, Kantor Pertanahan Batu seharusnya dapat menggunakan bahasa yang biasa digunakan oleh masyarakat setempat. Kantor Pertanahan Batu juga dapat meminta bantuan perangkat desa/kelurahan

14 Hasil wawancara dengan Bapak Agus Harianto, Kasi Hubungan Hukum Pertanahan Kota Batu. 
setempat untuk menjelaskan program tersebut. Hal ini disebabkan karena perangkat desa telah mengenal budaya masyarakat, sehingga dapat lebih dipahami oleh masyarakat.

Pihak selanjutnya yang memiliki hambatan dalam pelaksanaan PTSL yaitu Perangkat Kantor Desa/Kelurahan. Kantor Desa/Kelurahan memiliki peran dalam pengumpulan dokumen masyarakat yang ikut program PTSL. Namun, ketika sudah terjun ke masyarakat, hambatan-hambatan yang terjadi bersifat teknis, seperti pemilik tanah yang tidak diketahui keberadannya, obyek menjadi jaminan utang, klaim batas tanah yang tidak jelas, masyarakat tidak segera mengumpulkan dokumen. Permasalahan tersebut dapat diselesaikan ketika perangkat desa/kelurahan bersikap persuasif dan menjelaskan pentingnya sertifikat tanah. Perangkat Desa/Kelurahan melakukan sosialisasi pentingnya bukti kepemilikan tanah sehingga masyarakat dapat menjaga tanah mereka.

\section{Kepastian Hukum Penguasaan Tanah melalui Pendaftaran Tanah Sistematis Lengkap di Kota Batu}

Hukum dapat ditegakkan jika memperhatikan tiga unsur yaitu kepastian hukum, kemanfaatan, dan keadilan. Namun, dari ketiga unsur tersebut tidak dapat dititikberatkan pada salah satu unsur saja, karena tidak selalu mudah untuk mengusahakan timbulnya keseimbangan antara ketiga unsur tersebut. Kepastian hukum secara normatif merupakan suatu peraturan yang dibuat dan diundangkan secara pasti karena mengatur secara jelas dan logis. ${ }^{15}$ Tanpa adanya kepastian hukum, seseorang tidak tahu hal apa yang akan dilakukan dan akhirnya timbul perasaan tidak nyaman, namun ketika terlalu menitikberatkan pada suatu kepastian hukum, terlalu ketat mentaati suatu aturan akibatnya akan kaku dan menimbulkan ketidakadilan.
Kepastian hukum merupakan hal yang menjadi harapan subyek hukum untuk mengetahui hal yang dilarang ataupun tidak dilarang oleh hukum, sehingga perlu adanya suatu penormaan yang baik dan jelas dalam suatu peraturan perundang-undangan, serta jelas juga penerapannya di masyarakat. Kepastian hukum bukanlah suatu hal yang mutlak untuk memenuhi tujuan hukum, melainkan pada sebagai saran yang digunakan sesuai dengan situasi dan kondisi dengan memperhatikan asas manfaat dan efisiensi. Kepastian hukum apabila dikaitkan dengan pendaftaran tanah yang secara umum diatur dalam pasal 19 ayat (1) UUPA yang menyebutkan bahwa: ${ }^{16}$

"Untuk menjamin kepastian hukum oleh Pemerintah diadakan pendaftaran tanah di seluruh wilayah Republik Indonesia menurut ketentuan-ketentuan yang diatur dengan Peraturan Pemerintah."

Berdasarkan pasal tersebut, Pemerintah telah memberikan jaminan kepastian hukum dan perlindungan hukum bagi masyarakat untuk menguasai tanah yaitu melalui pendaftaran tanah.

Penguasaan tanah memiliki dua arti, yaitu arti fisik dan arti yuridis. Penguasaan tanah dalam arti yuridis merupakan penguasaan yang dilandasi oleh hak yang dilindungi oleh hukum dan memberikan kewenangan kepada pemegang hak untuk menguasai secara fisik tanah yang dihaki, seperti pemilik tanah menggunakan atau mengambil manfaat dari tanah yang dihaki, tidak diserahkan kepada pihak lain. ${ }^{17}$ Pasal 1 angka 2 Peraturan Pemerintah Nomor 16 Tahun 2004 tentang Penatagunaan Tanah menyebutkan bahwa penguasaan tanah merupakan hubungan hukum antara orang perorangan, kelompok masyarakat atau badan hukum dengan tanah sesuai dengan UUPA. Berdasarkan uraian tersebut maka dapat diketahui bahwa hak penguasaan tanah merupakan

15 Amran Suadi, et al., 2016, Politik Hukum: Perspektif Hukum Perdata dan Pidana Islam Serta Ekonomi Syariah, Kencana, Jakarta, hlm. 295.

16 Pasal 19 ayat (1) Undang-Undang Nomor 5 Tahun 1960 tentang Pokok-Pokok Agraria (Lembaran Negara Republik Indonesia Tahun 1960 Nomor 104, Tambahan Lembaran Negara Nomor 2043).

17 Urip Santoso, 2005, Hukum Agraria dan Hak-Hak Atas Tanah, Kencana, Jakarta, hlm. 73. 
serangkaian wewenang, kewajiban, dan atau larangan untuk berbuat sesuatu atau tidak berbuat sesuatu bagi pemegang haknya.

Salah satu hak penguasaan atas tanah menurut Hukum Tanah Nasional yaitu hak perseorangan atas tanah yang meliputi hak-hak atas tanah, wakaf tanah hak milik, hak tanggungan, dan hak milik atas satuan rumah susun..$^{18}$ Hak perseorangan atas tanah merupakan hak atas tanah sebagai hak individual yang semuanya secara langsung ataupun tidak langsung bersumber pada hak bangsa. ${ }^{19}$

Contoh dari hak perseorangan yaitu hak milik, hak guna usaha, hak guna bangunan, hak pakai, hak sewa, hak membuka tanah, hak memungut hasil hutan, hak-hak lain yang diatur dalam Pasal 53 UUPA. Upaya pemerintah untuk memberikan kepastian hukum terhadap penguasaan tanah kepada individu yaitu melalui pendaftaran tanah yang diatur dalam Peraturan Pemerintah Nomor 10 Tahun 1961 tentang Pendaftaran Tanah dan telah diperbarui dengan PP NO 24/1997. Bagi tanah yang belum melakukan pendaftaran tanah berdasarkan aturan tersebut maka tanah tersebut akan menjadi obyek pendaftaran tanah untuk pertama kali, baik secara sistematik maupun sporadis.

Pendaftaran tanah secara sistematik lebih diutamakan karena mempercepat perolehan data mengenai bidang-bidang tanah yang akan didaftar daripada melalui pendaftaran tanah secara sporadis. ${ }^{20}$ Implementasinya yaitu Program PTSL yang merupakan program percepatan pendaftaran tanah yang terlihat dari aturannya yaitu Permen ATR/BPN No 6/2018 dan Instruksi Presiden Nomor 2 Tahun 2018 tentang Percepatan Pendaftaran Tanah Sistematis Lengkap di Seluruh Wilayah Republik Indonesia. Kedua aturan tersebut merupakan landasan pelaksanaan PTSL di Indonesia.
Kota Batu yang merupakan salah satu wilayah yang menjalankan program ini juga menggunakan kedua aturan tersebut. Pemerintah menginginkan bahwa seluruh wilayah di Indonesia terdaftar dalam peta tunggal, sehingga seluruh wilayah khususnya di Kota Batu diukur dan didata. Tujuan utama pelaksanaan PTSL yaitu memberikan kepastian hukum kepada masyarakat dalam hal kepemilikan tanah dalam bentuk sertifikat tanah.

Perbedaan pendaftaran tanah pertama kali melalui PTSL dengan pendaftaran tanah pertama kali berdasarkan PP No 24/1997 yaitu terdapat pada pembayaran pajak peralihan tanah dan bangunan dan jangka waktu pengumuman. Pendaftaran tanah pertama kali secara sistematik yang di atur dalam PP No 24/1997 jika terdapat pemindahan hak atas tanah, maka kewajiban para pihak juga perlu melampirkan bukti pelunasan pembayaran Bea Perolehan Hak atas Tanah dan Bangunan (BPHTB) dan $\mathrm{PPh}^{21}$

Ketika bukti pembayaran pajak peralihan tersebut tidak dapat dilampirkan, maka sertifikat hak atas tanah masih belum bisa diterbitkan. Namun, hal ini berbeda dengan pendaftaran tanah melalui PTSL karena peserta PTSL yang masih memiliki tunggakan pembayaran BPHTB dan PPh maka masih tetap dapat diterbitkan sertifikat hak atas tanah dengan catatan peserta PTSL membuat surat pernyataan BPHTB dan/atau PPh terhutang. ${ }^{22}$ Apabila peserta PTSL tidak bersedia membuat surat pernyataan terhutang BPHTB dan/atau PPh, maka bidang tanah tersebut tidak dapat dibukukan dan diterbitkan sertifikat dan masuk dalam kluster 3 .

Perbedaan lain dapat ditemukan mengenai jangka waktu pengumuman. Pengumuman yang dilakukan oleh Panitia Ajudikasi jika berdasarkan Pasal 26 PP No 24/1997 menyebutkan bahwa hasil

\footnotetext{
Ibid, hlm 11.

9 Lihat Pasal 16 dan Pasal 51 Undang-Undang Nomor 5 Tahun 1960 tentang Pokok-Pokok Agraria (Lembaran Negara Republik Indonesia Tahun 1960 Nomor 104, Tambahan Lembaran Negara Nomor 2043).

20 FX. Sumarja, 2010, Hukum Pendaftaran Tanah, Universitas Lampung, Bandar Lampung, hlm. 41.

21 Lihat Pasal 103 Peraturan Menteri Negara Agraria Nomor 3 Tahun 1997 tentang Pelaksanaan Peraturan Pemerintah Nomor 24 Tahun 1997 tentang Pendaftaran Tanah.

22 Lihat Pasal 33 Peraturan Menteri Agraria dan Tata Ruang/Kepala Badan Pertanahan Nasional Nomor 6 Tahun 2018 tentang Pendaftaran Tanah Sistematis Lengkap (Berita Negara Republik Indonesia Tahun 2018 Nomor 501).
} 
pengukuran diumumkan selama 30 (tiga puluh) hari dalam pendaftaran tanah secara sistematik. Sedangkan pengumuman yang dilakukan dalam PTSL diatur dalam Pasal 24 Permen ATR/BPN No 6 Tahun 2018 yang menyebutkan bahwa pengumuman hanya dilakukan selama 14 (empat belas) hari kalender di Kantor Panitia Ajudikasi PTSL dan Kantor Kepala Desa/Kelurahan. Alasan Pemerintah mempersingkat waktu pengumuman karena PTSL merupakan pendaftaran tanah secara massal yang diketahui oleh masyarakat umum sehingga pengumumannya lebih singkat dan ketika ada sengketa tanah akan segera diketahui.

Luaran dari PTSL yang dilakukan oleh Kantor Pertanahan Kota Batu ternyata tidak hanya menerbitkan sertifikat tanah, melainkan juga peta bidang tanah dan daftar tanah. Tujuan dan target utama Program PTSL yaitu mengukur keseluruhan tanah-tanah yang meskipun tidak dapat diterbitkan sertifikat karena tidak dapat memenuhi persyaratan yang ada. Hal ini bertujuan agar dapat mewujudkan peta tunggal pertanahan di Indonesia. Pelaksanaan yang dilaksanakan oleh Kantor Pertanahan Kota Batu telah sesuai dengan Poin Kedua dari Instruksi Presiden Republik Indonesia Nomor 2 Tahun 2018 tentang Percepatan Pendaftaran Tanah Sistematis Lengkap di Seluruh Wilayah Republik Indonesia bahwa luaran dari pelaksanaan PTSL yaitu:

a. Kluster 1 yaitu bidang tanah yang memenuhi syarat yang diterbitkan sertifikat.

b. Kluster 2 yaitu bidang tanah yang hanya dicatat dalam buku tanah karena sedang dalam keadaan sengketa atau berperkara di Pengadilan

c. Kluster 3 yaitu bidang tanah yang hanya didaftarkan dalam daftar tanah karena subyek atau obyeknya belum memenuhi syarat PTSL atau tidak diketahui keberadaannya.

d. Kluster 4 yaitu bidang tanah yang terdaftar belum terpetakan dalam Peta Pendaftaran Aplikasi KKP.

Obyek PTSL di Kota Batu didominasi kepemilikan tanah yang termasuk kluster 1, yaitu tanah-tanah yang belum dilekati oleh hak atas tanah sesuai dengan ketentuan UUPA. Tanah tersebut masuk dalam obyek konversi hak. Konversi hak merupakan penyesuaian hak-hak atas tanah yang tunduk kepada sistem hukum yang lama, yaitu hakhak atas tanah menurut KUH Perdata dan hukum adat menjadi hak atas tanah menurut UUPA. ${ }^{23}$ Contoh bekas tanah milik ada sebelum diundangkan UUPA dibuktikan dengan petuk pajak bumi, girik, pipil, kekitir, dan verponding Indonesia, yang digantikan dengan Kutipan Letter $C$ yang dibuat oleh Kepala Desa/Kelurahan. ${ }^{24}$ Konversi hak dapat didaftarkan dengan pendaftaran tanah sistematik maupun sporadis dengan melengkapi alat-alat bukti mengenai adanya hak tersebut berupa buktibukti tertulis, keterangan saksi dan atau pernyataan yang bersangkutan yang kadar kebenarannya oleh Panitia Ajudikasi dalam pendaftaran tanah secara sistematik atau oleh Kepala Kantor Pertanahan dalam pendaftaran tanah secara sporadis, dianggap cukup untuk mendaftar hak, pemegang hak, dan hak-hak pihak lain yang membebaninya. ${ }^{25}$

PTSL dilakukan untuk mendapatkan kepastian hukum bagi pemegang hak atas tanah maupun pihak lain yang memiliki kepentingan dengan tanah yang dikuasainya tersebut. Kepastian hukum kepemilikan tanah dapat diwujudkan dengan penerbitan sertifikat tanah. Undang-Undang Pokok Agraria mengatur bahwa Pemerintah mengadakan pendaftaran tanah di seluruh wilayah Republik Indonesia yang bertujuan untuk menjamin kepastian hukum atas hak-hak atas tanah. ${ }^{26}$ Upaya mewujudkan kepastian hukum dalam pendaftaran tanah yaitu penerbitan sertifikat tanah. Sertifikat menurut PP No 24/1997 adalah berupa satu lembar

\footnotetext{
A.P Parlindungan, 1990, Konversi Hak-Hak Atas Tanah, Mandar Maju, Bandung, hlm. 5.

Urip Santoso, 2015, Perolehan Hak Atas Tanah, Kencana, Jakarta, hlm. 92.

Pasal 24 ayat (1) Peraturan Pemerintah Nomor 24 Tahun 1997 tentang Pendaftaran Tanah (Lembaran Negara Republik Indonesia Nomor 59 Tahun 1997, Tambahan Lembaran Negara Republik Indonesia Nomor 3696).

26 Urip Santoso, 2010, Pendaftaran dan Peralihan Hak atas Tanah, Prenada Media Group, Jakarta, hlm. 248.
} 
dokumen yang memuat informasi tentang data yuridis dan data fisik yang diperlukan terhadap suatu bidang tanah yang didaftarkan haknya.

Sertifikat tanah menghubungkan antara kepastian hukum bidang tanah dan pemegang hak. Sifat sertifikat tanah yaitu alat bukti yang kuat, tetapi hal yang ditegaskan dalam Pasal 19 ayat (2) PP No 24/1997 belum menjamin sepenuhnya kepastian dan perlindungan hukum bagi pemegang hak atas tanah. Hal ini disebabkan karena sistem pendaftaran tanah yang dianut Indonesia adalah sistem stelsel negatif bertendensi positif. Sehingga, segala yang tercantum dalam buku tanah dan sertifikat hak atas tanah berlaku sebagai tanda bukti yang kuat sampai dapat dibuktikan suatu keadaan sebaliknya yang tidak benar. ${ }^{27}$

Berdasarkan penelitian ini, bahwa PTSL memberikan kemudahan pada masyarakat untuk memperoleh sertifikat tanah dan Pemerintah akan memiliki peta tunggal terkait tanah di Indonesia. Selain itu, meskipun menyimpangi beberapa ketentuan dalam PP No 24/1997, khususnya berkaitan dengan penangguhan pembayaran pajak peralihan (BPHTB dan/atau PPh) dan jangka waktu pengumuman, kegiatan ini tetap memberikan kepastian hukum pada masyarakat dalam penguasaan tanah yang berasal dari kegiatan PTSL. Hal ini disebabkan karena kegiatan PTSL di Kota Batu dilakukan sesuai dengan ketentuan dalam Permen ATR/BPN No 6 Tahun 2018.

Kantor Pertanahan Kota Batu tidak ragu untuk menerbitkan sertifikat dari hasil PTSL, karena Indonesia menganut sistem publikasi negatif yang mengandung unsur positif. Artinya, semua keterangan yang terdapat dalam sertifikat tersebut mempunyai kekuatan pembuktian yang kuat sepanjang tidak ada bukti lain yang mengingkarinya. ${ }^{28}$ Ketika proses PTSL berlangsung hingga diterbitkannya sertifikat, Panitia tidak menemukan masalah. Permasalahan muncul ketika sertifikat telah diterbitkan, maka terhadap sertifikat tersebut masih ada kemungkinan untuk dibatalkan karena ada bukti kepemilikan yang sah sebelumnya. Pembatalan sertifikat juga dapat melalui putusan Pengadilan Negeri.

Terhadap obyek PTSL yang telah diketahui namun telah terjadi sengketa saat proses PTSL berlangsung, maka akan penerbitan sertifikatnya akan ditunda dan sengketanya diselesaikan sesuai dengan kluster tanah tersebut. Ketika obyek tersebut masih dalam jaminan perbankan, maka akan dibuatkan Surat Pernyataan oleh Kantor Pertanahan dengan ditandatangani Pemohon, bahwa ketika sertifikat tanah sudah diterbitkan oleh Kantor Pertanahan Kota Batu akan diserahkan kepada Bank terkait. Dalam hal ini perbankan tidak perlu khawatir apabila obyek jaminannya akan hilang karena program PTSL, melainkan bank akan diuntungkan karena penerbitan sertifikat tanah akan menambah nilai dari tanah tersebut.

Permasalahan-permasalahan yang terjadi lebih kepada persoalan teknis pelaksanaan PTSL. Meskipun persyaratan dalam Program PTSL dapat dikatakan sederhana, namun tetap saja ketelitian Panitia Ajudikasi dalam pengecekan data yuridis dan fisik harus ditingkatkan. Obyek tanah yang ikut dalam program PTSL di Kota Batu ketika terdapat sengketa seharusnya penerbitannya dapat ditunda terlebih dahulu hingga sengketa tersebut selesai. Hal ini akan berkaitan dengan pemberian jaminan kepastian hukum kepemilikan tanah yang diwujudkan dengan penerbitan sertifikat. Meskipun sertifikat merupakan alat bukti yang kuat dan dapat dibatalkan ketika ada pihak yang menggugatnya, namun ketika hal tersebut dapat dihindari, maka masyarakat dapat memegang sertifikat tersebut dengan tenang dan Pemerintah dapat mewujudkan cita-citanya untuk memiliki peta tunggal.

\footnotetext{
Adrian Sutedi, 2012, Sertifikat Hak Atas Tanah, Sinar Grafika, Jakarta, hlm. vi.

Arifin Bur, et al., "Sertifikat sebagai Alat Pembuktian yang Kuat dalam Hubungannya dengan Sistem Publikasi Pendaftaran Tanah", VIR Law Review, Vol. 01, No. 02, Oktober 2017, hlm. 127-136.
} 


\section{Kesimpulan}

PTSL di Kota Batu khususnya di Desa Oro-Oro Ombo dan Kelurahan Dadaprejo telah dilaksanakan sesuai dengan Permen ATR/BPN No 6/2018. Hambatan yang ditemui hanya berkaitan dengan yang bersifat teknis, seperti administrasi yang belum lengkap, alat bukti kepemilikan tanah masih dijaminkan, pemilik yang tidak ada saat pengukuran, dan jumlah petugas ukur yang masih sedikit.

Terdapat perbedaan pada pelaksanaan PTSL di beberapa ketentuan dalam PP No 24/1997, khususnya yang berkaitan dengan penangguhan pembayaran pajak peralihan (BPHTB dan/atau $\mathrm{PPh})$ dan jangka waktu pengumuman. Walaupun demikian, kegiatan ini tetap memberikan kepastian hukum pada masyarakat dalam penguasaan tanah yang berasal dari kegiatan PTSL khususnya di Kota Batu. Hal ini disebabkan karena kegiatan PTSL di Kota Batu dilakukan sesuai dengan ketentuan dalam Permen ATR/BPN 6/2018. Selain itu, tujuan utama dari pelaksanaan PTSL yaitu agar Pemerintah memiliki peta tunggal terkait pertanahan di Indonesia.

\section{DAFTAR PUSTAKA}

\section{A. Buku}

Mertokusumo, Sudikno, 2006, Hukum Acara Perdata Indonesia, Liberty, Yogyakarta.

Parlindungan, A.P, 1990, Konversi Hak-Hak Atas Tanah, Mandar Maju, Bandung.

Suteri, Adrian, 2012, Sertifikat Hak Atas Tanah, Sinar Grafika, Jakarta.

Suadi, Amran, et al., 2016, Politik Hukum: Perspektif Hukum Perdata dan Pidana Islam Serta Ekonomi Syariah, Kencana, Jakarta.

Sumarja, FX, 2010, Hukum Pendaftaran Tanah, Universitas Lampung, Bandar Lampung.

Santoso, Urip, 2005, Hukum Agraria dan Hak-Hak Atas Tanah, Kencana, Jakarta.

Santoso, Urip, 2010, Pendaftaran dan Peralihan Hak atas Tanah, Prenada Media Group, Jakarta.

Santoso, Urip, 2015, Perolehan Hak Atas Tanah, Kencana, Jakarta.

\section{B. Artikel Jurnal}

Bur, Arifin, et al., "Sertifikat sebagai Alat Pembuktian yang Kuat dalam Hubungannya dengan Sistem Publikasi Pendaftaran Tanah", VIR Law Review, Vol. 01, No. 02, Oktober 2017.

\section{Artikel Majalah}

Badan Pusat Statistik Kota Batu, "Statistik Daerah Kota Batu 2016”, Publikasi Statistik Daerah Kota Batu 2016, September 2016.

\section{Internet}

Hutapea, Erwin, "Tak Selalu Berjalan Mulus, Pendaftaran Tanah Terkendala Empat Hal", https://properti.kompas.com/read/2018/ 12/17/183000721/tak-selalu-berjalanmulus-pendaftaran-tanah-terkendala-empathal? page $=$ all, diakses pada tanggal 10 April 2019.

Ihsanuddin, "Jokowi: Prona Sudah 35 Tahun, baru 44 Persen Tanah Warga Bersertifikat", https://nasional.kompas.com/read/2016/ 10/16/12474581/jokowi.prona.sudah.35. tahun.baru.44.persen.tanah.warga. bersertifikat, diakses 12 November 2018.

Mastur, Roy, "Bpn Beri 514 Sertifikat Gratis Kota Batu", http://www.rri.co.id/post/ berita/248262/daerah/bpn_beri_514_ sertifikat_gratis_kota_batu.html, diakses 17 juni 2017.

\section{E. Peraturan Perundang-undangan}

Undang-Undang Nomor 5 Tahun 1960 tentang 
Pokok-Pokok Agraria (Lembaran Negara Peraturan Pemerintah Nomor 24 Tahun 1997 Republik Indonesia Tahun 1960 Nomor 104, tentang Pendaftaran Tanah (Lembaran Tambahan Lembaran Negara Nomor 2043). Negara Republik Indonesia Nomor 59 Tahun Peraturan Menteri Agraria dan Tata Ruang/Kepala 1997, Tambahan Lembaran Negara Republik Badan Pertanahan Nasional Republik Indonesia Nomor 3696).

Indonesia Nomor 6 Tahun 2018 tentang Peraturan Menteri Negara Agraria Nomor 3 Tahun Pendaftaran Tanah Sistematis Lengkap 1997 tentang Pelaksanaan PP 24 Tahun 1997 (Berita Negara Republik Indonesia Tahun tentang Pendaftaran Tanah. 2018 Nomor 501). 